УДК [311.21:551.588.7]:061.1€С:005.336.4

JEL Classification: C13, C18, Q53, Q54

Doi: 10.31767/su.1(92)2021.01.01

O. H. Osaulenko,

DSc in Public Administration, Professor,

Corresponding Member of the National Academy of Sciences of Ukraine,

Honored Economist of Ukraine,

Rector,

National Academy of Statistics, Accounting and Audit,

E-mail: o.osaulenko@nasoa.edu.ua

ResearcherID: F-3856-2018,

ORCID: https //orcid.org/0000-0002-7100-7176;

T. V. Kobylynska,

DSc in Economics,

Deputy Head of the Chief,

Statistics Division in Zhytomyr Region of the State Statistics Service of Ukraine,

E-mail:TVstat@i.ua

ResearcherID: N-2678-2018,

ORCID: https //orcid.org/0000-0001-8376-9656

\title{
Climate Change Statistics: European Experience and National Assessment
}

Climate change is one of the most serious threats to the society, economy and environment in the whole world and Ukraine in particular. The central objective for the environmental statistics today is to perform the sound statistical assessment, to develop or improve new or existing approaches to building up the system for accounting of the indicators measuring climate change and adaptation to it. The improvement or development of existing or new methodologies and methods for the statistical accounting and assessment of climate change indicators is the only way for the production of information in a sound and comprehensive manner. It is argued that the statistical analysis allows deepening the grasp into the operation of a complex and dynamic phenomena as climate change, elaborate actions to reduce its adverse environmental effect, and eliminate adverse consequences of climate change for our planet.

It is found that the official statistics have been put the ever stronger focus on issues of environmental performance and climate change by concentrating on the development and improvement of methodologies and procedures for compilation of environmental accounts that are used for economic measurements of natural resources, energy, waste, water resources, air emissions, spending for environmental protection. It is stressed the United Nations Statistical Commission has adopted, at global level, the System of Environmental-Economic Accounting (SEEA) designed to provide important support to the development of statistics related with climate change by intensifying the effort in several dimensions of the complex economic and environmental accounting. The industry coverage of the climate change statistics is defined, with a detailed description of various approaches to the environmental accounting in which indicators of climate change are involved. The significance of the environmental-economic accounting (and the account of air emission of dangerous substances in particular) as the central source of data on greenhouse gas emissions in Ukraine is substantiated.

In spite of many functions in the measurement of climate change, assigned to the national statistics system, the existing official statistics does not always employ its capacities for the assessment of climate change. By considering the statistics on climate change as a tool with impact on decision-making in this field, the authors outlined the areas of improvements in the accounting of climate and climate change.

Key words: statistics on climate change, environment, statistical system, greenhouse gas emissions, environmental-economic accounting.

Introduction. Climate change is referred to in Article 1 of the United Nations Framework Convention on Climate Change (UNFCCC). As follows from UNFCCC, climate change is caused, directly or not, but human activities, it provokes change in the composition of the global atmosphere and overlaps on the natural fluctuations of climate,

(c) O. H. Osaulenko, T. V. Kobylynska, 2021 observed over comparable periods of time. The term "climate system" is interpreted in UNFCCC as a combination of atmosphere, hydrosphere, biosphere, geosphere, and their interactions. The term "unfavorable consequences of climate change" is defined by UNFCCC as "change in the physical environment of habitat, caused by climate change, which has very negative impact on the composition, reproductive capacity or productivity of natural 
and regulating ecosystems, or on the operation of socio-economic systems, or on the human health and welfare" [1;2].

Climate change is a global problem which solution requires essential and diversified information. Experts from National Aeronautic and Space Administration (NASA) believe that climate change will affect humans across the globe. It is expected that the increased global temperature will raise the sea level, change the precipitation pattern and other regional climate conditions. Change in the regional climate will, in its turn, affect forests, crop yield, water stocks and health of humans, animals and nearly all the types of ecosystem. Deserts will spread up to existing mountain ranges, and national park and national forest area will be continually changing.

The definition of greenhouse gas (GHG) emission follows the methodology elaborated by Intergovernmental Panel on Climate Change (IPCC). Climate change combat is a global challenge calling for a wide-scale international cooperation which principles are set out in a series of successively signed agreements: UNFCCC [1; 2], Kyoto Protocol [3], Paris Agreement [4]. The latter was entered into force on November 4, 2016 and signed by 195 countries, including the group of powerful economies, given that the tools envisaged by the two earlier agreements failed to achieve essential reduction of GHG emission. In view of the goal, to hold the increase in global average temperature below $2^{\circ} \mathrm{C}$ above pre-industrial levels, the parties of Paris Agreement have to balance the sources of GHG emission and absorption in the second half of the current century or achieve the actual zero net global GHG emission till the year of 2100. The goals of Ukraine conform to the global goal of Paris Agreement, with collaborative international actions supposed to be critical for their achievement.

The article's objective is to elaborate and substantiate the principles of statistical production and assessment of information on climate change, adaptation to it, to outline the actions for monitoring of adaption to climate change, and to create environmental and economic mechanisms for management of their implementation.

Adverse effects of business operation for the environmental performance in Ukraine have been addressed by Ukrainian economists: B. Danylyshyn, S. Dorohuntsov, M. Khvesyk, V. Mesel-Veseliak, V. Semenov, I. Sivachenko, V. Fedoriak, M. Fedorov. Problems of the statistical assessment of environmental effects are addressed in works of V. Danylko, A. Yerina, N. Parfentseva, O. Yelisieieva. But the Ukrainian statistics still lacks fundamental works that would deal with issues of climate change statistics in a comprehensive manner.

Research results. The Verkhovna Rada of Ukraine ratified Paris Agreement on 14.07.2016 [4]. It was before it that the Cabinet of Ministers of
Ukraine had issued the Directive from 16.09.2015 No 980 to approve the Expected Nationally Fixed Contribution to the draft of this agreement [5]. It was declared in it that in 2030 Ukraine would not exceed $60 \%$ of the GHG emission level in 1990, and further revision of this ambitious contribution was made conditional on the socio-economic indicators. Besides that, to improve the current climate policy, the Cabinet of Ministers of Ukraine issued the Directive from 07.12.2016 No 932-p to approve the Guidelines for Implementation of the National Policy in Climate Change till 2030 [6]. The Guidelines outline the following objectives: enhance the institutional capacity for setting and implementing the climate change policy; prevent climate change by reducing anthropogenic emissions, increasing GHG absorption, and by gradual adoption of low carbon development of the country; adapt to climate change, enhance the resistance to climate change and reduce the related risks. The Directive from 06.12.2017 No 878-p by the Cabinet of Ministers of Ukraine approved the Action Plan for Implementation of the above mentioned Guidelines, involving a set of specific measures, their deadlines and the offices responsible for the implementation [7].

The importance of the statistical assessment of socio-economic dimensions of climate change and its effects for the sustainable development is stressed in research works [8; 9]. The national statistics system (NSS) of Ukraine provides statistical data in this field for inventories of anthropogenic GHG emission sources and GHG absorbers at national level, for preparing the national cadaster of anthropogenic emissions and GHG absorption and submitting the national report (cadaster) of anthropogenic emission sources and GHG absorbers to UNFCCC Secretariat.

The official statistics has recently put the increasingly stronger emphasis on environmental and climate issues, with focus on the elaboration and improvement of methodologies and procedures for compilation of environmental accounts used as a tool for recording environmental-economic interactions, allowing for economic measurement of natural resources, energy, water resources, air emissions, and spending on environmental protection [10-12].

UN Statistical Commission approved the global System for Environmental-Economic Accounting (SEEA). This new standard is intended to provide important support for the development of climate change statistics through creating a database of the indicators related with climate change. SEEA contains internationally agreed concepts, definitions, classifications, rules of accounting and a table for creating comparable statistical data on the environment and its relationship with the economy [13].

In spite of many responsibilities assigned to NSS in the measurement of climate change, the existing official statistics does not always employ its 
capacities for the assessment of climate change. If the climate change statistics is considered as a tool with impact decision-making process, improvements will be required in the statistical accounting of climate and climate change. It should be remembered that the current official statistics is not designed for analyses of climate change. Hence, NSS has to be transformed in a way to provide for a better response on the needs of all the users of data and estimates pertaining to climate change. This will obviously require the elaboration of new methods for dissemination of official statistics and data collection, which may provoke reorganizations in the NSS system as whole.

Today, NSS can offer many data about various dimensions of socio-economic and environmental life of the country. But often it does not pay special attention to the prevention of data duplication and to the measurement of relationships between the respective branches of statistics. Determining and modeling of interactions may often be a task for economists, researchers, analysts, experts from government ministries and others who work outside the statistics system. The models constructed by them put emphasis on climate change caused by humans (and not by the nature), in view of the fact that climate is a system consisting of several components (atmosphere, hydrosphere, etc.) and their interactions, and climate change will have inevitable effects for the environment and socioeconomic dimensions of human life.

How can the statistical system contribute to the measurement (accounting) of climate change? The statistical system has many specifics in data collection and accounting, which are important in the context of climate change. The official statistics adheres to international principles and standards in this field, formulated as result of numerous discussions on climate change, which have a number of important features [14; 15]. In spite of sometimes controversial character of this discourse, one of these features is professional independence and impartiality. The official statistics is able to be an important source of reliable and sound information by virtue of strict terms and quality criteria by which it is produced. Other principles include the commitment to justified, transparent and commonly accepted methodologies, and to the assurance of data accessibility. The official statistics is focused on the measurement of the activities of legal entities (enterprises), physical persons and households. Monitoring of the environmental performance, climate change and adaptation to it is usually conducted outside the statistical system. But it may catch some data on environment and climate, related with industries or households whose actions have environmental impact. The official statistics may often contain a reference to a geographic area. In some countries accurate spatial coordinates are received by use of geo-reference, and this practice needs to be rapidly expanded, because the spatial dimension is extremely important in the context of climate change.

One challenge for the development of statistics related with climate change is establishing effective coordination and task-sharing between national public administration bodies concerned with this field. This can be achieved by creating a unit in statistical offices, responsible for this field of action. A separate problem for NSS will be building up new statistics for analysis of climate change, for example monitoring of progress towards an environmentally friendly structure of production and consumption.

The environmental performance has been continuously worsening. Nature preservation, e. g. through reducing emissions of dangerous substances by all the pollution sources, needs to be a priority area of government and community actions. The socioeconomic development strategy and the national environmental policy need to be set and implemented in a coordinated and complementary manner, because the healthy nation is closely and integrally related with the environmental and social growth.

A national economy in our times is impossible without due accounting for the environmental component.Aseriesofimportantdocumentspertaining to the environmental policy regulation were approved in Ukraine in the last year, including the Action Plan for Realization of Guidelines for Implementation of the National Policy on Climate Change; the Strategy for Low Carbon Development of Ukraine till 2050 was elaborated; works to elaborate and approve the regulatory acts required for the implementation of the Law of Ukraine "Principles of Monitoring, Reporting and Verification of Greenhouse Gas Emissions" were launched [16].

Sound statistical data are expected to lay the ground for the effective decision-making on the active response to climate change. Official statistics bodies in Ukraine make critical contribution in the national effort aiming to enhance the official statistics capacity required for conducting climate assessments and making up national reports. This area of research contributes to the dimension of Sustainable Development Goals (SDGs) concerned with climate change and its consequences, i. e. it is related with SDG 13. It requires the elaboration of a methodology for constructing a set of key indicators related with climate change, which was approved by the Conference of European Statisticians in 2017 [17].

It was in 2009 that the United Nations Statistical Commission (UN SC) made a review of the European Statistical System (ESS) program related with climate change, and the official statistics. The review was based on a document prepared by the Australian Statistical Office and summed up in 2008 at two conferences in this field. The approval of one of the review outcomes resulted in the UN SC's recognition of the important contribution made by NSSs in 
eliminating gaps in data on climate change, and in the emphasis on the necessity for deeper understanding of the stakeholders' needs in statistical data [18, p. 38].

In view of the above, the Bureau of EU Committee decided, in 2011, to analyze the current performance of NSSs in issues of climate change statistics, with addressing a request to the United Nations Economic Commission for Europe (UNECE) to conduct a survey in UNECE and EC member countries. This survey implemented with support from the UN Committee of Experts on Environmental-Economic Accounting and the UN Statistics Division in NewYork City, covered 69 countries, as it was conducted inside and outside the UNECE area. Of 48 countries that filled a questionnaire, 37 reported about the involvement in the effort on the compilation of cadasters (inventories) of GHG emission (CGHGE), and 18 reported about the elaboration of other fields of statistics related with climate change. The respondents covered the survey recognized the need for international efforts aiming to determine ways by which the data provided by NSSs could be more effectively used in analyses of climate change and relevant policy setting. They also said that if climate change were analyzed in all its dimensions, it would help integrate the data on climate change that were often produced outside NSSs with the official statistical data on environment. Although the survey results give grounds to suggest that actions aiming to achieve this integration have already been on, they could also demonstrate the real capacities for subsequent improvements and reforms.

The Target Group on climate change statistics was established by the Bureau of EU Committee, to determine practical steps for support of future developments in the statistics related with climate change, and to increase the contribution of the official statistics in the compilation of CGHGE. Governments of the majority of developed countries have published information on GHG emissions for many years, using a well-established reporting procedure implemented under UNFCCC aegis. While NSSs most often provide input data for calculations of GHG emissions, report makers are usually located outside NSSs [19; 20]. The official statistics related to climate change is far less established, although several statistical divisions have already started working in this field.

Large scopes of the available official statistical information on issues of environmental, social and economic statistics could be used much more effectively in policy setting and analyses of climate change. According to the European recommendations, NSSs should have closer cooperation with CGHGE designers, which would allow the official statistics to meet the needs related with CGHGE maintenance.

Given a large scope of statistical data required for cadasters, it is recommended to recognize all the NSSs as official units in the CGHGE system. Such national cadaster systems [19] are created and used to ensure transparence, consistency, comparability, completeness and accuracy of cadasters by way of planning, preparation and organization of the effort on their maintenance. The process of this effort is country specific. It is desirable to create national work groups responsible for CGHGE compilation and other issues of the statistics related with climate change. We believe that the mechanism for production of the data for the national cadaster will be effective if the responsibility for data completeness and quality is shared by the State Statistics Committee as a supplier of input data for computations of GHG emissions, and the Ministry for Protection of Environment and Natural Resources of Ukraine as a supplier of output data on GHG emissions for purposes of international reporting.

National statistical divisions are recommended to use a consistent approach and rely on their functional competencies when the works on quality improvement of the statistics related with climate change are launched. For purposes of analyses of climate change, they should focus on structural improvements in the already available environmental and socio-economic statistics. Thus, official channels of dissemination of statistical information could be used more effectively due to the opened access to them for researchers and policy makers in the field of climate change. The second step should concern with making the available statistical data more applicable for purposes of analyses of climate change by improving the existing data collection systems, which would allow the official statistics to more fully address the needs of CGHGE maintenance. Thus, it is desirable that the available data be presented as more general geo-coded information, to allow for their link with the respective environmental indicators. The link of the available data sets is important as it makes them more consistent and maximally useful for analyses of climate change. The third necessary step is a review of issues related with collection of new statistical data, e. g. ones on factors provoking climate change, its socio-economic consequences, efforts for their mitigation, exposure and adaptation to climate change.

National statistical divisions as parts of NSSs need:

$\checkmark \quad$ to act as a supervisor-assistant of cadaster designers by assessing the usefulness of the available statistical information for the designers;

$\checkmark$ to improve the quality of statistical data using international recommendations resulted from review of national cadasters;

$\checkmark$ to analyze statistical needs pertaining to Kyoto Protocol [3] and other global or regional agreements on climate change;

$\checkmark$ to be constantly ready to meet new data needs. 
The contribution of international statistical organizations should be their involvement in the processes that follow international agreements on climate and pertain to the global CGHGE system.

NSSs will face new challenges when working over the above mentioned issues. Thus, the official statistics cannot be effectively used for analyses of climate change unless the standard classifications, registers, definitions and survey methods are revised. Not less important is finding new ways to ensure the confidentiality of official statistics, when analysts addressing the problem of climate change will be given wide access to microdata. NSSs need to acquire new expert knowledge, e. g. through training, recruiting of professionals and, first and foremost, setting up partner relations with other designers of information and experts. In the long-term perspective, NSSs may feel the need in organizational change with providing support to designers of the statistical data that would be applicable across the statistical system.

The Target Group was he first one to elaborate recommendations intended to help NSSs improve the quality of statistics related with climate change. Their implementation needs to be supported by continuing efforts at international level. This can be achieved by initiating a regular international forum for exchanging best practices, strengthening cooperation, discussing priority needs in data, issues on basic sets of statistical indicators related with climate change, and outlining of directions for further methodological works.

The global nature of climate change requires the expansion of cooperation between users and producers of statistical information, to allow for more effective response on the growing needs in information.
At international level, it is necessary to harmonize statistical standards and guidelines as a way to ensure comparability of data and effective use of resources. Later on, international statistical organizations (e. g. the Conference of European Statisticians and its Secretariat) have to set up cooperation with UNECE, the Intergovernmental Panel on Climate Change, the World Meteorological Organization and others.

Because climate change has environmental and social effects due to complex interactions and causalities, the conceptual framework for creating the statistics that would cover many industries should reflect a widest possible range of the data and be maximally complete. Climate change is caused by most part of anthropogenic activities like energy and transport, agriculture, manufacturing, tourism, etc. (as the sources generating waste), on the one hand, and affects them, on the other hand. In fact, only some of the human activities are not related in a way with climate change. But the latter has impact on a wide range of natural phenomena (rainfalls, temperature, and air flows) and ecosystems as a whole, which also have impact on the anthropogenic activities.

The coverage of statistics related with climate change is shown in Figure 1 (developed by the authors). Its components are as follows:

$>$ environmental, social and economic data measuring anthropogenic causes of climate change (emissions and factors);

$>$ the impact of climate change on anthropogenic and natural systems;

$>$ social efforts to prevent the consequences of climate change;

$>$ social efforts to adapt to climate change.

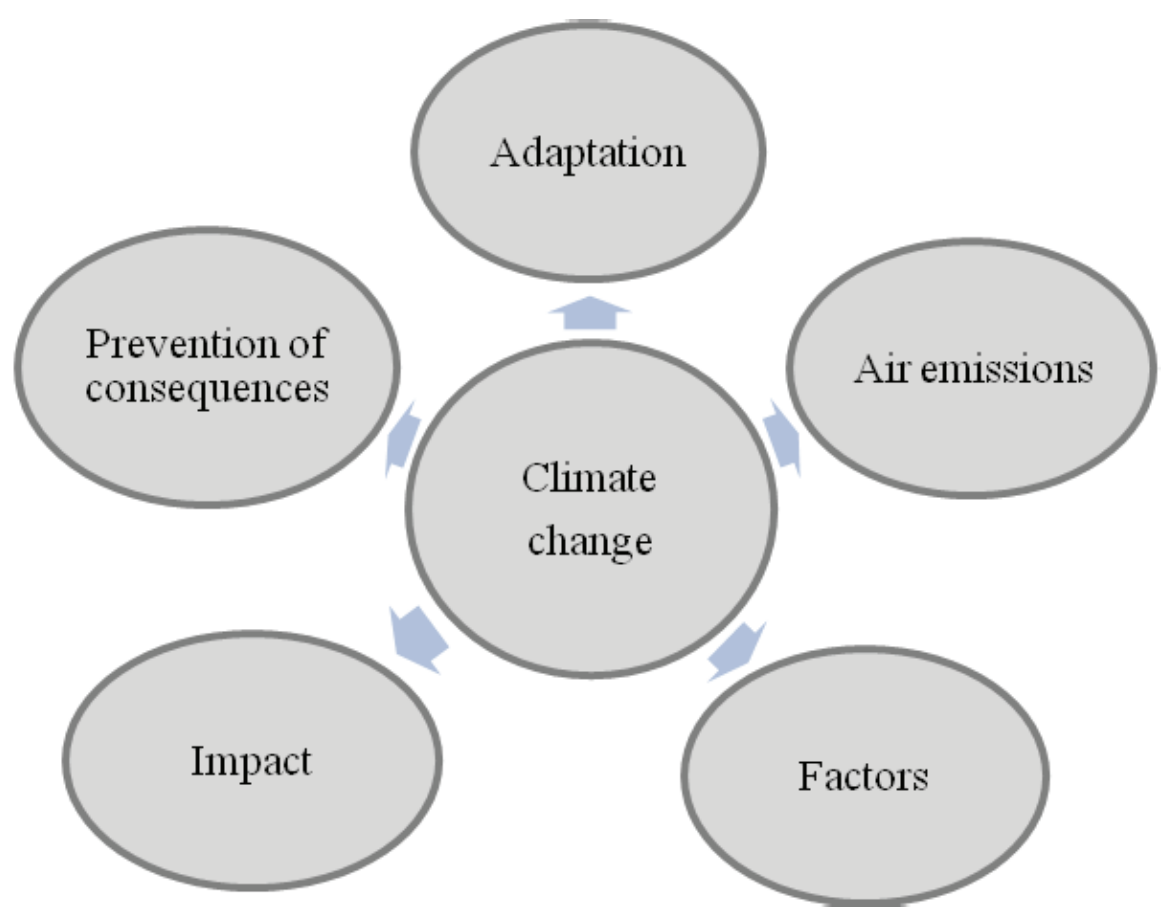

Figure 1. The coverage of statistics related with climate change 
Climate studies are based on the interdisciplinary approach heavily relying on natural sciences, with the statistics focused on anthropogenic systems and providing data by administrative regions within the national borders. But this approach has to be adopted as only a starting point for NSSs in their effort to improve the statistics related with climate change. A professional approach must be elaborated, to confine the coverage to the components for which statistical systems will be the most useful. In some of the spheres the correlation between anthropogenic and natural systems is critical for studies of climate change in view of its causes and impacts. When assessing the impact, one may sometimes need to resort to interpretative or value judgments.

Official statisticians should focus on things that need to be measured and support analysts in their effort to identify and assess the impacts of climate change. It follows that the NSS objectives must pertain to information support for the impact assessment rather than the impact assessment as such.

It is necessary to distinguish between statistics related with climate change and statistics on climate change. In the latter case the data are obtained through direct measurements of climate indicators and weather, e. g. temperature or precipitations. These data are often (but not always) collected and analyzed by units not incorporated in the statistical system, such as meteorological offices.

NSSs must improve the quality of data required for the compilation of CGHGE jointly with the units responsible for CGHGE compilation, including statistics of power generation and supply, industry, transport, agriculture, waste, forestry and land use. NSSs must concentrate on the following issues and actions, to harmonize and optimize the works on CGHGE:

1. Raising the awareness of the ways official statistical data are used or could be used in CGHGE, to account for the respective needs in data. The statistical data available with NSSs now are not fully employed for the compilation of CGHGE. Moreover, when the data are collected, the effort of the statistical system and other organizations may be duplicated, a practice that needs to be ended by clarifying the available categories of statistics. NSSs, with their coordination function, should raise the awareness of the data that are already available in the system, and of the way they can be employed for CGHGE purposes.

2. CGHGE should be based on official statistics, and additional data need to be collected only when the former are not applicable for CGHGE purposes. This work should be conducted with due consideration to the recommendations of the Intergovernmental Panel on Climate Change on use of data for the assessment of GHG emissions. NSSs jointly with other institutions must ensure the best possible use of the existing statistics for estimating CGHGE indicators. This can help improve the quality of GHG emission estimates and their consistency with other statistical data.

3. NSSs needs to initiate improvements the quality of statistical data used for CGHGE. An important source of information for identifying the needs related to the improvement of data quality can be national reports on cadasters, provided on UNFCCC request by national CGHGE designers, and annual reports of cadaster review prepared by expert groups of UNFCCC. The re-compilations of data on GHG emissions, contained in national reports on cadasters, made by ISIC will improve their coherence with other statistical data.

4. In view of the importance of a good energy balance as the basis for CGHGE, special emphasis should be made on the improvement of the quality of energy statistics, including energy accounts in keeping with SEEA. Professional statisticians specializing in power production and supply (either in NSSs or in other organizations) must seek to improve the conformity of CGHGE data on operation with energy balances reported to international organizations (such as Eurostat or International Energy Agency).

5. It is important to remember about gaps in data, especially in ones on agriculture, land use and forestry. Although these sectors' contribution to the total GHG emission is relatively low in most part of countries, the estimates of these emissions are very uncertain now.

6. A number of countries emphasize the need to eliminate the gaps in some data, especially in ones on generation of waste, production of electricity for internal consumption and renewable energy sources. CGHGE analysts could benefit from timely reporting of the data by activity, including the data on energy balances.

7. The competence of NSS staff dealing with dynamic series allows them to construct, in course of CGHGE analysis, the longer series, in particular the ones on emission source.

8. The wide-scale cooperation with national cadaster designers in determining and assessing the statistics required for CGHGE would help clarify whether or not the data meet the objective. The work can be started with preparing, jointly with cadaster designers, a list of data gaps at national level, with setting up priorities in their elimination, and a roadmap for improvements in data design, to enhance the quality of national statistics used in CGHGE. The statistics developed in NSSs must conform with the priorities set for each country by analysis of the fields where effective amendments can be made. Moreover, NSSs should be considered as official units in CGHGE compilation in all the countries. The legal framework for the development of these systems is Kyoto Protocol [3]. 
The following considerations should push NSSs to identify their contribution in CGHGE compilation:

$>$ Promoting cooperation of cadaster designers with the statistical system could be part of NSS functions as a coordinator of national data on climate change. In view of this, NSSs should explore the needs in data and be actively involved in operation of the national cadaster system.

$>$ A national working group incorporating NSS, cadaster designers and other stakeholder organizations should be established. Its current work tasks should be information exchange, reviews of the existing statistics, identifications of duplications in reporting of data and fields where effective cooperation can be set up, and problem discussions. Its long-term task may be cost reduction due to eliminated duplications, harmonization of data and introduction of multi-profile data systems addressing the needs of various user categories.

$>$ NSSs reporting a large part of statistical data required for CGHGE compilation should be assigned a clearly defined function in the provision of statistical data, support in computations (in case of need), and quality assurance. This function must be fixed in official agreements, e. g. the agreement on the inclusion of NSSs in the national systems responsible for CGHGE. This approach would eliminate uncertainties in issues concerned with functions and duties of each unit, and closer cooperation would help improve the quality of CGHGE. It can be achieved by indicating the function of NSS in the cadaster documents provided on UNFCCC request, or in a more official way, by signing a memorandum on mutual understanding between NSS and an official unit responsible for CGHGE.

$>$ NSS practices in the information quality assurance are a valuable contribution in the improvement of CGHGE quality. The European Statistics Code of Practice [21] and the United Nations Fundamental Principles of Official Statistics [22] lay the firm institutional ground for collecting sound and unbiased statistical information that can be used in cadasters. Also, it is necessary to stress the importance of the relieved respondent burden and the overall cost effectiveness in all the statistical actions; these two dimensions are not always highlighted in the guidelines on CGHGE compilation. NSSs could exercise cross checks of data when comparing cadaster estimates with other statistical data, to find incomparable figures in cadasters. This approach is usually effective in identifying errors. The international statistical community should increase its contribution in promoting the global CGHGE. As standards, classifications and methods for CGHGE compilation and production of official statistics on GHG emissions are developed and harmonized by international agreements, this calls for a higher effectiveness of the dialogue between international organizations, including international statistical organizations addressing climate problems.

The international statistical community and NSSs give due consideration to the need for establishing closer cooperation between international statistical organizations (at European level - the Conference of European Statisticians of UNECE and its Secretariat), UNFCCC and others. First and foremost, the consolidated cooperative effort at this level allows elaborating the methods for cadaster compilation by which only the available data have to be accounted for, without the need in the information that tends to be missing in most part of countries. This would also reduce inconsistencies with international requirements before data collection and reporting. The intensive cooperation at country level with national UNFCCC offices has to be focused on addressing issues related with data, commentaries on cadaster maintenance, and cadaster verifications. The approval of further actions by results of sessions of the Conferences of UNFCCC Parties would help guarantee timely and effective formulation of requirements to new or updated data obtained by results of the above mentioned sessions, thus reducing the costs of the global system and improving the cadaster quality. The statistical community is capable to increase the utility of cadasters by assessing the availability of data and meeting the requirements set by Kyoto Protocol, and to ensure the readiness to meet potential new needs in the data. If NSSs of the countries that need to respond on the requirements to new data are involved in this effort from the beginning, it will help assess the feasibility of reporting these data and prevent the creation of duplicating systems for data presentation. The 17th session of the Conferences of UNFCCC Parties launched negotiations to sign a single new international agreement that would allow making all the entities that are main sources of emissions in developed and developing countries observe the single legal framework. Also, the existing international network of NSSs is able of intensifying exchange of practices related with the improvement of cadaster quality, e. g. by organizing expert sessions, disseminating information bulletins or using other communication means.

Hence, NSSs must increase the official statistics contribution in analyses of climate change. An early step along the way has to concern with simplifying the access to statistical data available in each NSS. The following tasks need to be implemented by NSSs for this purpose:

1) Create national forums for discussions between designers and users of statistics related with climate change, e. g. meteorological organizations and the scientific community. These discussions can help NSSs in identifying most relevant statistical data and pressing needs in new statistical data. 
2) Encourage the inclusion of the available official statistics in analyses of climate change. If the stakeholders are informed about the available data, it will help prevent duplications in data collection activities.

3) Use the channels for dissemination of NSS data, to open access to the statistics related with climate change. These data may include the ones not produced by NSS (such as scientific data). Statistical data required for understanding the causes and consequences of climate change are currently collected by various organizations. The creation of a web-portal to display statistics related with climate change as a data dissemination channel will make the data more accessible and simply usable. This web portal can be a single center for the maintenance of data and metadata, covering a wide range of the available data on climate change. It would require the established cooperation with research organizations. For example, meteorological services have long dynamic series of climatic variables (temperature, precipitations, etc.), and this information can be provided together with NSS data.

4) Develop (explore) new methods for protecting confidentiality of respondent data, to broaden the access to microdata for researchers addressing problems of climate change.

Besides that, it is necessary to improve the applicability of the available environmental, social and economic statistics for analyses of climate change, e. g. through it better structuring. It involves the following tasks to be solved by NSSs:

- Review the statistical methods and procedures for data collection in view of the needs in data for analyses of climate change, e. g. for clarifying if they can be applied for obtaining statistical information with sufficient detailing, including the one on renewable energy, environmentally friendly jobs, production of foods, water use, health and deceases, tourism, population and its growth. This work has to be done effectively, with highlighting national priorities. It can include tasks on regular verifications as an integral component of each statistical system or involve verification activities as part of new development projects. Even simple corrections made in the data collection procedure are able to improve their applicability for analyses of climate change, which will enhance the effectiveness of utilization of limited resources. Users can be offered help in performing such analyses, to identify the essential fields requiring further improvements.

- Solve the problems with linking data from various fields of statistics and inconsistencies between data sets. NSSs should make emphasis on closer links between the sets of socio-economic and environmental data by improving the conformity of methodology and practice.
- Geo-link all the data concerned, to support analyses of special data related with climate change. It will also help improve the link of the available data with the data on climate change and other environmental data. A good example is the support provided by European NSSs to INSPIRE program [23].

- Develop statistical data for new geographic areas, e. g. coastal ones or areas exposed to floods or droughts. Additional statistical data on city areas or small areas are especially needed by the developed countries. Much more often sample surveys cannot ensure a sufficient coverage for obtaining statistical data on small areas.

- Develop new statistical data in NSSs by the results of analyses of essential information needs of policy makers and analysts addressing the problem of climate change. This task should be solved with bearing in mind the main tasks of NSS and due consideration to the traditional operation boundaries of the systems (NSSs are usually not involved in preparations of forecasts or formulating analytical conclusions).

The assessment of NSS performance enables to outline critical functional areas with gaps in obtaining and accumulation of key data, which must be subject to special attention. These areas may be the following:

1. Analyses the factors provoking climate change and launch of the effort on linking economic information with data on climate change by developing or improving environmental accounts, which would enable to link data on GHG emissions and water use with data on economic activities. Practical applications of CGHGE for supporting measurements in the industries related with climate change should be considered as an important strategic task for NSSs. Also, international statistical organizations should address the issue of finding most effective ways for providing support to countries in CGHGE applications [13; 14].

2. Design of statistics on utilization of economic tools as part of the effort on mitigating climate change, for performance analyses of new tools (e. g. tax on carbon, emission trade quotas, subsidies). It is necessary to address the issue of measurements of financial flows related with utilization of these tools, and the inclusion clear, consistent and comparable estimates of these flows in the official financial statistics and national accounts.

3. Design of statistics for the assessment of adaptation to climate change and adaptation capacities, e. g. for measurements of risks and vulnerability of population groups, and the society's readiness to counteract adverse effects of climate change. The respective indicators should be constructed for the population groups exposed to risks of disasters or risks of poverty dueto climate change. 
4. Discussions of issues related with methods of participation in the monitoring of ecosystem biodiversity. Climate change is an anthropogenic factor concerned with the ecosystem and production of goods and services. The development of basic indicators of the current ecosystem performance will allow to improve the reliability of estimates of effects of climate change. As the outlined tasks and actions go far beyond the boundaries of the routine NSS operation, their implementation requires the established cooperation with organizations responsible for the quality of ecosystems.

Conclusions, recommendations, and prospects of future studies. Summing up, it should be noted that the review of the existing systems of classifications, registers, definitions, statistical tools, products and services allows to determine if they are capable to adequately meet the needs related with analysis of climate change. Subject to assessment should be the legal framework for the development of statistics related with climate change and the issues of providing support for CGHGE compilation. The following recommendations are proposed as a roadmap for addressing these problems:

- Future efforts on revisions of international statistical standards and classifications should consider the needs in data for analyses of climate change, e. g. by amendments of national account systems, to improve the quality of statistics on emissions trade in conformity with the guiding principles of IPCC/UNFCCC. A revision is required for classification related with industry, education, employment, trade, etc. If these classifications allow for the easy extraction of statistical data related with climate change, NSSs will be able to quickly obtain and collect new statistical data with reliance on the already available statistics. The improved quality of classifications will help obtain data about climate-related sectors such as education, research, jobs, low carbon industries, green technologies, biotechnological products, and international trade flows.

- Identify and eliminate barriers for the harmonization of data on various fields of statistics, e. g. environmental statistics and statistics of power generation and supply. The harmonization must be cross-industry and between industries and the national accounts system. Examples may be studies of differences in concepts in the power generation and supply across statistics fields, harmonization of data across reporting institutions, and checks of used data on resources, to link inputs and outputs in the industry with the utilization of energy and air emissions.

- Adopt new methods for the protection of confidentiality of respondent data in providing access to microdata for researchers addressing the problem of climate change. In most countries the confidentiality of data is ensured by the acts on statistics, being an essential precondition for the development of reliable official statistics. Any predictable decisions must, therefore, be backed by the current legal framework. Some countries have chosen the approach by which the responsibility for the components of CGHGE compilation process, requiring confidential data, is put on NSS. The opening of access to more detailed data without violating the confidentiality terms may require new technological decisions, e. g. applications of tools for information retrieval, capable to produce requests of microdata via a website.

The implementation of these recommendations requires creation of new partnerships, acquisition of expert knowledge and skills for the introduction of a new methodology for the development of statistics related with climate change. Future studies are expected to focus on the implementation of international recommendations in building up the national information system for constructing indicators on climate change.

\section{References}

1. Ramkova Konventsiia OON pro zminu klimatu: mizhnarodnyi document, ratyfikovanyi Ukrainoiu 29.10.1996 r. № 995_044 [United Nations Framework Convention on Climate Change. An International Document, ratified by Ukraine on October 29, 1996 No. 995_044]. zakon.rada.gov.ua. Retrieved from https://zakon.rada.gov.ua/laws/show/995_044\#Text [in Ukrainian].

2. Pro ratyfikatsiiu Ramkovoi Konventsii OON: Zakon Ukrainy vid 29.10.1996 r. № 435/96-VR [On ratification of the UN Framework Convention: Law of Ukraine of October 29, 1996 No 435/96-VR]. zakon.rada.gov.ua. Retrieved from https://zakon.rada.gov.ua/laws/show/435/96-\%D0\%B2\%D1\%80\#Text [in Ukrainian].

3. Kiotskyi protokol do Ramkovoi Konventsii OON pro zminu klimatu: mizhnarodnyi document, ratyfikovanyi Ukrainoiu 04.02.2004 r. № 995_801, stanom na 17.11.2006 r. [Kyoto Protocol to the UN Framework Convention on Climate Change. An International Document, ratified by Ukraine on February 04, 2004 No. 995_801, as of November 17, 2006].zakon.rada.gov.ua. Retrieved from https://zakon.rada.gov.ua/ laws/show/995_801\#Text [in Ukrainian].

4. Paryzka Uhoda: mizhnarodnyi document, ratyfikovanyi Ukrainoiu 14.07.2016 r. № 995_161 [Paris Agreement. An International Document, ratified by Ukraine on July 17, 2016 No 1469-VIII]. zakon.rada.gov.ua. Retrieved from https://zakon.rada.gov.ua/laws/show/995_161\#Text [in Ukrainian]. 
5. Pro skhvalennia Ochikuvanoho natsionalno vyznachenoho vnesku Ukrainy do proektu novoi hlobalnoi klimatychnoi uhody: Rozporiadzhennia Kabinetu Ministriv Ukrainy vid 16.09.2015 r. № 980-r. [On approval of the Intended Nationally-Determined Contribution (INDC) of Ukraine to a New Global Climate Agreement. Decree of the Cabinet of Ministers of Ukraine of September 16, 2015 No 980-r]. zakon.rada.gov.ua. Retrieved from https://zakon.rada.gov.ua/laws/show/980-2015-\%D1\%80\#Text [in Ukrainian].

6. Kontseptsiia realizatsii derzhavnoi polityky u sferi zminy klimatu na period do 2030 roku: skhvalena rozporiadzhenniam Kabinetu Ministriv Ukrainy vid 07.12.2016 r. № 932-r [The Concept for the implementation of the state policy in the field of climate change for the period up to 2030. Approved by the Order of the Cabinet of Ministers of Ukraine of December 07, 2016 № 932-r]. wrew.kmu.gov.ua. Retrieved from https://www.kmu. gov.ua/npas/249573705 [in Ukrainian].

7. Pro zatverdzhennia planu zakhodiv shchodo vykonannia Kontseptsii realizatsii derzhavnoi polityky u sferi zminy klimatu na period do 2030 r.: Rozporiadzhennia Kabinetu Ministriv Ukrainy vid 06.12.2017 r. № 878-R [On approval of the action plan for the implementation of the Concept of implementation of state policy in the field of climate change for the period up to 2030: Order of the Cabinet of Ministers of Ukraine of December 06, 2017 No 878-R]. zakon.rada.gov.ua. Retrieved from https://zakon.rada.gov.ua/laws/show/8782017-\%D1\%80\#Text [in Ukrainian].

8. Basic Set of Environment Statistics. (2018). unstats.un.org. Retrieved from https://unstats.un.org/ unsd/envstats/fdes/basicset.cshtml

9. Pro osnovni zasady (stratehiiu) derzhavnoi ekolohichnoi polityky Ukrainy na period do 2020 roku: Zakon Ukrainy vid 21.12.2010 r. № 2818-VI, vtrata chynnosti vid 01.01.2020 r. [On the basic principles (strategy) of the state ecological policy of Ukraine for the period up to 2020. Law of Ukraine of December 21, 2010 No 2818-VI, was repealed on January 01, 2020]. zakon.rada.gov.ua. Retrieved from https://zakon.rada. gov.ua/laws/show/2818-17\#Text [in Ukrainian].

10. Metodolohichni polozhennia zi skladannia rakhunku vykydiv v atmosferu: zatverdzheni Nakazom Derzhstatu Ukrainy vid 07.09.2020 r. № 268. [Methodological regulations for constructing an account of the emissions into air. Approved by the Order of the State Statistics Service of Ukraine of September 07, 2020 No. 268]. wrew.ukrstat.gov.ua. Retrieved from http://www.ukrstat.gov.ua/norm_doc/2020/268/268.pdf [in Ukrainian].

11. Metodolohichni polozhennia z orhanizatsii derzhavnoho statystychnoho sposterezhennia shchodo vykydiv zabrudniuiuchykh rechovyn ta parnykovykh haziv v atmosferne povitria vid statsionarnykh dzherel zabrudnennia: zatverdzheni Nakazom Derzhstatu Ukrayiny vid 31.12.2019 r. № 454 [Methodological regulations on design of the state statistical observation on emissions of pollutants and greenhouse gases into air from stationary sources of pollution. Approved by the Order of the State Statistics Service of Ukraine of December 31, 2019 No. 454]. www.ukrstat.gov.ua. Retrieved from http://www. ukrstat.gov.ua/norm doc/2019/454/454.pdf [in Ukrainian]. Methodological regulations

12. Metodolohichni polozhennia zi skladannia dopomizhnoho (satelitnoho) rakhunku vytrat na okhoronu navkolyshnoho pryrodnoho seredovyshcha: zatverdzheni Nakazom Derzhstatu Ukrainy vid 29.12.2018 r. № 297 [Methodological regulations for constructing an subsidiary (satellite) Environmental Protection Expenditure Account. Approved by the Order of the State Statistics Service of Ukraine of December 29, 2018 № 297]. wrwro.ukrstat.gov.ua. Retrieved from http://www.ukrstat.gov.ua/metod_polog/metod_doc/2018/297/mp_ dr_ons.pdf [in Ukrainian].

13. System of Environmental-Economic Accounting (SEEA). seea.un.org. Retrieved from https://seea. un.org/

14. System of Environmental-Economic Accounting 2012 - Central Framework. (2014). ST/ESA/STAT/Ser.F/109. seea.un.org. Retrieved from https://seea.un.org/sites/seea.un.org/files/seea_cf_final_en.pdf

15. Pro zatverdzhennia Stratehii rozvytku derzhavnoi statystyky do 2017 roku: Rozporiadzhennia Kabinetu Ministriv Ukrainy vid 20.03.2013 r. № 145-r. [On approval of the Strategy for the development of state statistics until 2017. Order of the Cabinet of Ministers of Ukraine of March 20, 2013 No. 145-r]. zakon.rada.gov.ua. Retrieved from https://zakon.rada.gov.ua/laws/show/145-2013-\%D1\%80\#Text [in Ukrainian].

16. Pro zasady monitorynhu, zvitnosti ta veryfikatsii vykydiv parnykovykh haziv: Zakon Ukrainy vid 12.12.2019 r. № 377-IX [On Principles of Monitoring, Reporting and Verification of Greenhouse Gas Emissions. Law of Ukraine of December 12, 2019 No. 377-IX]. zakon.rada.gov.ua. Retrieved from https://zakon.rada.gov. ua/laws/show/377-20\#Text [in Ukrainian].

17. Supporting countries to achieve the SDGs. wrew.unece.org. Retrieved from http://www.unece.org/ info/about-unece/mission/unece-and-the-sdgs.html 
18. Conference of European Statisticians Recommendations on Climate Change-Related Statistics. (2014). wrw.unece.org. Retrieved from https://unece.org/DAM/stats/publications/2014/CES_CC_ Recommendations.pdf

19. Ukraine's Greenhouse Gas Inventory 1990-2018 (draft). Annual National Inventory Report for Submission under the United Nations Framework Convention on Climate Change and the Kyoto Protocol (2020). mepr.gov.ua. Retrieved from https://mepr.gov.ua/files/docs/Zmina_klimaty/2020/Ukraine_ NIR_2020\%20draft.pdf

20. Poriadok provedennia natsionalnoi inventaryzatsii antropohennykh vykydiv iz dzherel ta pohlynannia pohlynachamy parnykovykh haziv [Procedure for a national inventory of anthropogenic emissions by sources of removals by sinks of greenhouse gases]. (2008). wroro.carbonunitsregistry.gov.ua. Retrieved from http://www.carbonunitsregistry.gov.ua/ua/publication/10 [in Ukrainian].

21. Kodeks praktyky yevropeiskoi statystyky [European Statistics Code of Practice]. (2017). wrero.ukrstat.gov.ua. Retrieved from http://www.ukrstat.gov.ua/md/doc/Code_of_practice.pdf [in Ukrainian].

22. Fundamental principles of official statistics. unece.org. Retrieved from https://unece.org/statistics/ fundamental-principles-official-statistics

23. Core Writing Team, Pachauri, R. K., \& Meyer, L. A. (Eds.). (2014). Climate Change 2014: Synthesis Report.Contribution of Working Groups I, II and III to the Fifth Assessment Report of the Intergovernmental Panel on Climate Change. Geneva, Switzerland: IPCC. Retrieved from https://www.ipcc.ch/site/assets/ uploads/2018/02/SYR_AR5_FINAL_full.pdf

\author{
О. Г. Осауленко, \\ доктор наук з державного управління, професор, \\ член-кореспондент Національної академії наук України, \\ заслужений економіст України, \\ ректор, \\ Національна академія статистики, обліку та аудиту, \\ E-mail: o.osaulenko@nasoa.edu.ua \\ ResearcherID: F-3856-2018 \\ ORCID:https //orcid.org/0000-0002-7100-7176; \\ T. В. Кобилинська, \\ доктор економічних наук, \\ заступник начальника, \\ ГУС у Житомирській області Держстату України, \\ E-mail: TVstat@i.ua \\ ResearcherID: N-2678-2018 \\ ORCID: https //orcid.org/0000-0001-8376-9656
}

\title{
Статистика зміни клімату: європейський досвід та національна оцінка
}

Зміна клімату є однією з найсерйозніших загроз для суспільства, економіки та навколишнього природного середовища світу й України зокрема. Сьогодні головне завдання статистики екології - проводити якісне статистичне оцінювання, розробляти нові й удосконалювати існуючі підходи до побудови системи обліку показників, які характеризують зміну клімату та адаптацію до цих змін. Тому удосконалення чинних і розробка нових методологічних та методичних підходів до статистичного обліку й оцінки показників зміни клімату є єдиним шляхом до якісного та комплексного статистичного виробництва інформації. У статті зазначено, що завдяки статистичному аналізу й оцінюванню можна отримати найбільш повне уявлення про функціонування такого складного і динамічного явища, розробити заходи з метою скорочення його негативного впливу на навколишнє природне середовище та елімінування негативних наслідків зміни клімату для нашої планети.

Виявлено, що останнім часом офіційна статистика все більше зосереджується на питаннях навколишнього середовища та клімату, надаючи перевагу розробці й удосконаленню методології та організаційних процесів складання екологічних рахунків, що слугують для економічного вимірювання природних ресурсів, енергії, відходів, водних ресурсів і викидів в атмосферу, а також витрат на охорону навколишнього середовища. Зазначено, що Статистична комісія ООН прийняла на глобальному рівні систему еколого-економічного обліку, яка надає важливу підтримку розвитку статистики, пов’язаної зі зміною клімату, шляхом посилення роботи над окремими аспектами комплексного економічного й екологічного обліку. Визначено галузеве охоплення статистики зміни клімату а також надано детальний 
опис різних підходів до екологічного обліку, в яких розглядаються показники зміни клімату. Обгрунтовано роль еколого-економічного обліку (зокрема рахунку викидів небезпечних речовин в атмосферне повітря) як головного джерела даних щодо емісії парникових газів в Україні.

Незважаючи на багато компетенцій, які має національна статистична система щодо вимірювання зміни клімату, існуюча офіційна статистика не завжди використовує для їі оцінки свій потенціал. Розглядаючи статистику зміни клімату як інструмент впливу на прийняття рішень у цій сфері, автори окреслили аспекти удосконалення статистичного обліку щодо клімату та кліматичних змін.

Ключові слова: статистика зміни клімату, навколишне природне середовище, статистична система, викиди парникових газів, еколого-економічний облік.

Bibliographic description for quoting:

Osaulenko, O. H., \& Kobylynska, T. V. (2021). Climate Change Statistics: European Experience and National Assessment. Statystyka Ukrainy - Statistics of Ukraine, 1, 4-15. Doi: 10.31767/su.1(92)2021.01.01.

Бібліографічний опис для цитування:

Осауленко О. Г., Кобилинська Т. В. Статистика зміни клімату: європейський досвід та національна оцінка (публікується англійською мовою). Статистика Украйни. 2021. № 1. С. 4-15.

Doi: 10.31767/su.1(92)2021.01.01. 